IZA DP No. 7627

The Role of the Exchange Rate Regime in the Process of Real and Nominal Convergence

Gaetano D'Adamo

Riccardo Rovelli

September 2013 


\title{
The Role of the Exchange Rate Regime in the Process of Real and Nominal Convergence
}

\author{
Gaetano D'Adamo \\ University of Valencia \\ Riccardo Rovelli \\ University of Bologna \\ and IZA
}

\section{Discussion Paper No. 7627 \\ September 2013}

\author{
IZA \\ P.O. Box 7240 \\ 53072 Bonn \\ Germany \\ Phone: +49-228-3894-0 \\ Fax: +49-228-3894-180 \\ E-mail: iza@iza.org
}

\begin{abstract}
Any opinions expressed here are those of the author(s) and not those of IZA. Research published in this series may include views on policy, but the institute itself takes no institutional policy positions. The IZA research network is committed to the IZA Guiding Principles of Research Integrity.

The Institute for the Study of Labor (IZA) in Bonn is a local and virtual international research center and a place of communication between science, politics and business. IZA is an independent nonprofit organization supported by Deutsche Post Foundation. The center is associated with the University of Bonn and offers a stimulating research environment through its international network, workshops and conferences, data service, project support, research visits and doctoral program. IZA engages in (i) original and internationally competitive research in all fields of labor economics, (ii) development of policy concepts, and (iii) dissemination of research results and concepts to the interested public.
\end{abstract}

IZA Discussion Papers often represent preliminary work and are circulated to encourage discussion. Citation of such a paper should account for its provisional character. A revised version may be available directly from the author. 


\title{
ABSTRACT \\ The Role of the Exchange Rate Regime in the Process of Real and Nominal Convergence
}

\begin{abstract}
During the last decade, economists have intensively searched for evidence on the importance of the Balassa-Samuelson (B-S) hypothesis in explaining nominal convergence. One general result is that B-S can at best explain only part of the excess inflation observed in the European catching-up countries, which suggests that other factors may be at play. In these and related studies, however, the potential role of the exchange rate regime in affecting price convergence in Europe has been overlooked. In this respect, we claim that the choice of the exchange rate regime has decisively affected the path of nominal convergence. To show this, we first model the (endogenous) choice of the exchange rate regime and, in a second stage, estimate a B-S type of regression for each regime. Our results show that, for countries which pegged to or adopted the euro, the effect of the same increase in the dual productivity growth (that is, the difference in productivity growth between the traded and nontraded sectors) on the dual inflation differential is more than twice as large as that in the "flexible" countries. We conclude that, in a catching-up country, premature euro adoption may foster excess inflation, beyond that which is to be expected as a consequence of productivity convergence on the basis of the B-S effect.
\end{abstract}

JEL Classification: C34, E52, F31

Keywords: exchange rate regimes, Balassa-Samuelson effect, inflation, euro adoption

Corresponding author:

Gaetano D'Adamo

Department of Applied Economics II

University of Valencia

Av.da dels Tarongers s/n

46022 Valencia

Spain

E-mail: gaetano.dadamo@uv.es 


\section{Introduction}

The aim of this paper is to study the process of real and nominal convergence in Europe, accounting for the role of the exchange rate regime in the catching up process. By making international prices comparison easier and removing one source of variability, a fixed exchange rate regime - and, even more so, entry in a monetary union - can foster price convergence at a higher speed with respect to real convergence.

As postulated by the Balassa-Samuelson (B-S) hypothesis, in a catching-up country there will be a comparatively higher inflation, of a structural nature, as prices of non-traded goods and services "catch up" with the growth of productivity in those sectors producing tradable goods and services. With respect to this benchmark hypothesis, we argue that, as a consequence of premature adoption of a fixed exchange rate regime, a higher inflation might follow, induced by the adoption of a fixed exchange rate, as this might stimulate faster price convergence in the nontradable sectors, beyond that which is implied by the B-S effect. This will be our first tested hypothesis. Furthermore, it is possible that this additional inflation "contaminates" the wage and price setting process in the sectors producing tradable goods and services. If this also happens, then premature fixing of the exchange rate might be accompanied by loss of competitiveness and large international imbalances, and thus become in principle unsustainable. Whether this additional effect (which is suggested by the recent experience of some Southern European countries ${ }^{1}$ ) can be empirically documented is the second hypothesis which we will test.

The focus of this paper will be on European countries that are in the process of catching up - which we identify as having a level of GDP per capita lower than $75 \%$ of the average of EU-15 countries at the initial date of our sample. We select these countries as they either have recently joined the euro, or are expected to do so in due time. The variety of exchange rate regimes adopted by these countries in recent years provides a good opportunity to study the effects that different regimes might have on the process of real and nominal convergence.

Research on this topic has generally focused on the B-S effect (Balassa 1964, Samuelson 1964). Studies on transition countries (see, for example, Egert, Halpern and MacDonald 2006) often focus on B-S as a possible rationale for explaining the excess inflation observed in these countries vis-à-vis the euro area. The B-S hypothesis states that countries which are in the process of catching up experience

\footnotetext{
${ }^{1}$ For instance, Kasimati and Verarios (2013) observe that "the result of Greece's accession to the EMU in January 2001 was a rapid deterioration in both its fiscal and current account deficits". One may also add that the second deterioration took place much more promptly than the first one. The same authors observe that the current account deficits were mostly due to "mounting losses in competitiveness".
} 
real exchange rate appreciation (measured in CPI terms); this is due to the fact that productivity grows faster in the tradable goods sector than in the non-tradables sector. In the first sector, productivity gains translate into wage increases which, through free inter-sectoral labor mobility, are then transferred throughout the economy. The increase in wages in the non-tradables sector, in turn, pushes up the prices of non-traded goods, which ultimately causes the increase in the CPI that determines real appreciation. The literature that focused on convergence in the last decade has been using alternative approaches ${ }^{2}$ to measure the importance of the B-S effect but, broadly speaking, the main result seems to be that such effect can account only for a minor part of the excess inflation observed (see Egert 2007). These results appear to suggest that other factors may indeed be at play ${ }^{3}$.

Quite surprisingly, however, the literature on convergence that flourished in the last decade has so far left aside the role of the exchange rate regime in the process of convergence. This is surprising because there is a wide strand of literature showing robustly that exchange rate regimes affect macroeconomic performance, for example growth (Levy-Yeyati and Sturzenegger 2003) and inflation dynamics (Ghosh et al. 2007). Moreover, as recently stated by Krugman (2013), "After the creation of the euro, (...) there was massive capital movement from Europe's core mainly Germany, but also the Netherlands - to its periphery, leading to an economic boom in the periphery and significantly higher inflation rates in Spain, Greece, etc. than in Germany". This is confirmed by Figure 1 below, which shows the amount of credit from the rest of EMU as a share of GDP for five euro area "catching up" countries: Greece, Portugal, Cyprus, Slovenia and Slovakia. ${ }^{4}$

\section{[ Insert Figure 1 here ]}

To take into account the effects of the exchange rate regime, however, induces substantial complications in the empirical analysis, as we need to estimate alternative models of the B-S effect, depending on the exchange rate regime in place, since the choice of the regime itself is endogenous.

Our contribution is thus twofold: first, as stated above, we propose and implement a way to measure the role of the exchange rate regime in accelerating price

\footnotetext{
2 The approaches used in the literature can be divided in three groups: descriptive statistics or an accounting framework (see for example Begg et al. [1999] and Dobrinsky [2006]); time series econometrics (Golinelli and Orsi [2002], and Egert [2002]) and panel econometrics (Klau and Mihaljek [2003], Egert [2002], Fischer [2004]).

${ }^{3}$ One effect that has been suggested in particular is related to Engel's law, which postulates that, during the catching up process, consumers move to higher-quality goods, thus indirectly pushing up the observed CPI (Egert and Podpiera 2008, Egert 2010).

${ }^{4}$ As euro adoption is generally anticipated, for example when a country joins ERM-II, then we should see expect the ratio of foreign credit to GDP ratio to increase substantially even before euro adoption. This is clearly shown in Figure 1.
} 
convergence; this requires modeling the choice of the exchange rate regime. ${ }^{5}$ Second, by establishing a link between the exchange rate regime and the decoupling of price and productivity convergence, we provide one rationale why adopting the euro "too early" may entail a potentially high cost in terms of competitiveness, for countries whose convergence process is still far from being completed.

The paper is structured as follows: in section 2 we present a general formulation of the B-S effect, along the lines of Froot and Rogoff (1995); section 3 describes the empirical approach; in section 4 we introduce the dataset and section 5 reports the results on the choice of the exchange rate regime. In section 6 , the different estimates of the B-S effect across regimes are discussed. In section 7 we tentatively assess whether the choice of the exchange rate regime has had additional implication on the competitiveness of catching up countries. Section 8 summarizes and concludes.

\section{A stylized model of the B-S effect}

Froot and Rogoff's (1995) model of the B-S effect is the main theoretical reference for researchers who, in the last decade, have been trying to measure the importance of the B-S effect in explaining the excess inflation experienced by transition and catching-up countries. In their model, there are two countries: home $(\mathrm{H})$, which is in the process of catching up, and a foreign $(\mathrm{F})$, more developed country. There are two sectors, one producing traded goods and services $(T)$ and one producing non-tradables $(N)$. Production in both sectors uses only two inputs, capital $(K)$ and labor $(L)$. Capital is freely mobile across sectors and across countries, and this ensures international and inter-sectorial equalization of the rental rate of capital, $R: R_{\mathrm{H}}=R_{\mathrm{F}}$. Labor, instead, is freely mobile across sectors but it is not internationally mobile. This ensures that we have inter-sectoral wage equalization in each country: $W_{\mathrm{H}, \mathrm{T}}=W_{\mathrm{H}, \mathrm{N}}=W_{\mathrm{H}} ; W_{\mathrm{F}, \mathrm{T}}=W_{\mathrm{F}, \mathrm{N}}=W_{\mathrm{F}}$ but at the same time also that $W_{\mathrm{H}} \neq W_{\mathrm{F}}{ }^{6}$

The production function is Cobb-Douglas for each country and sector:

$$
Y_{T, H}=A_{T, H} K_{T, H}^{1-\alpha} L_{T, H}^{\alpha}
$$

\footnotetext{
5 Throughout the paper we refer to de facto rather than de jure exchange rate classification of exchange rate regimes.

${ }^{6}$ While the assumption that labor does not move across countries may look too strong for countries which are member states of the European Union, where free mobility of goods, people and services is guaranteed by the Treaties, it is actually confirmed by the evidence that only $4 \%$ of workers in the E.U. come from a different E.U. member state, against an average of $33 \%$ in the U.S. Thus, notwithstanding the freedom of labor mobility, other barriers (mainly linguistic and cultural) still keep the E.U. labor market far from being a perfectly integrated one.
} 


$$
\begin{gathered}
Y_{N, H}=A_{N, H} K_{N, H}^{1-\beta} L_{N, H}^{\beta} \\
\mathrm{Y}_{\mathrm{T}, \mathrm{F}}=\mathrm{A}_{\mathrm{T}, \mathrm{F}} \mathrm{K}_{\mathrm{T}, \mathrm{F}}^{1-\gamma} \mathrm{L}_{\mathrm{T}, \mathrm{F}}^{\gamma} \\
\mathrm{Y}_{\mathrm{N}, \mathrm{F}}=\mathrm{A}_{\mathrm{N}, \mathrm{F}} \mathrm{K}_{\mathrm{N}, \mathrm{F}}^{1-\vartheta} \mathrm{L}_{\mathrm{N}, \mathrm{F}}^{\vartheta}
\end{gathered}
$$

where we have specified the production functions with sufficient generality to allow for different relative labor intensities across sectors and countries, i.e. $\alpha \neq \beta \neq \gamma \neq \delta$.

Call $P_{\mathrm{T}}$ the price of traded goods and $P_{\mathrm{N}}$ the price of non-traded goods. Profit maximization implies that the rental rate of capital and wages in each sector and country will equate the marginal products. Taking logs of (1)-(4) and solving the maximization problem yields the internal version of the B-S effect (note: lower case letters indicate logs, dots indicate changes):

$$
\dot{\mathrm{p}}_{\mathrm{N}, \mathrm{H}}-\dot{\mathrm{p}}_{\mathrm{T}, \mathrm{H}}=\frac{\beta}{\alpha} \dot{\mathrm{a}}_{\mathrm{T}, \mathrm{H}}-\dot{\mathrm{a}}_{\mathrm{N}, \mathrm{H}}
$$

i.e. the differential growth rate between the prices of non-traded and traded goods has the opposite sign and increases with the absolute value of the productivity growth differential. The reason is clear: as productivity grows faster in the traded goods sector, and wages are equalized across sectors, firms in $N$ will need to increase prices faster than in $\mathrm{T}$, to keep up with the surge in labor costs. This difference will be larger, the higher the share of labor in the production of nontraded goods relative to traded goods.

Moreover, note that as long as firms in $N$ are more labor intensive than in $T$, i.e. $\beta>\alpha$, non-traded goods prices will tend to grow faster with respect to the prices of traded goods even if there is a balanced growth of productivity in the two sectors. This leads us to the first Proposition of the B-S effect, (BS1):

Proposition BS1 (Internal B-S Effect). In a catching up country, $N$ goods prices grow at a higher rate than $T$ goods prices. The difference between $N$ goods inflation and $T$ goods inflation will be higher the higher the productivity growth differential between $T$ and $N$, and the more production of $N$ is relatively labor-intensive.

The two-country version of (5) is therefore simply:

$$
\left(\dot{\mathrm{p}}_{\mathrm{N}, \mathrm{H}}-\dot{\mathrm{p}}_{\mathrm{T}, \mathrm{H}}\right)-\left(\dot{\mathrm{p}}_{\mathrm{N}, \mathrm{F}}-\dot{\mathrm{p}}_{\mathrm{T}, \mathrm{F}}\right)=\left(\frac{\beta}{\alpha} \dot{\mathrm{a}}_{\mathrm{T}, \mathrm{H}}-\dot{\mathrm{a}}_{\mathrm{N}, \mathrm{H}}\right)-\left(\frac{\vartheta}{\gamma} \dot{\mathrm{a}}_{\mathrm{T}, \mathrm{F}}-\dot{\mathrm{a}}_{\mathrm{N}, \mathrm{F}}\right)
$$

i.e. excess relative inflation at Home with respect to the Foreign country (the dual inflation differential) is determined by the difference between dual productivity (productivity growth in the traded vs. non-traded goods sector) at home and 
abroad (the dual productivity differential). Proposition BS2 formally states this result, also known as the External B-S Effect:

Proposition BS2 (External B-S Effect). For a catching up country, the dual inflation differential, i.e. the difference between non-traded vs. traded goods inflation with respect to the foreign country, is proportional to the dual productivity differential, i.e. the difference between traded and non-traded productivity growth with respect to the foreign country. Other things equal, dual inflation differential will be higher the more $N$ is relatively laborintensive in the Home country with respect to the Foreign country.

The dual inflation differential may also be defined as the change in relative terms of trade. Let us now call $\sigma_{i}$ the share of traded goods in the CPI of country i, so that $1-\sigma_{\mathrm{i}}$ is the share of non-traded goods. We thus have:

$$
p_{i}=\left(1-\sigma_{i}\right) p_{N}+\sigma_{i} p_{T} ; i=H, F
$$

where $p_{\mathrm{i}}$ is the CPI index in country $i$. Given the definition of the real exchange rate (written in terms of changes):

$\dot{\mathrm{q}}=\dot{\mathrm{e}}+\dot{\mathrm{p}}_{\mathrm{F}}-\dot{\mathrm{p}}_{\mathrm{H}}$

we can plug first (7) and then (5) into (8), to end up with the B-S hypothesis for the real exchange rate:

$$
\dot{\mathrm{q}}=\dot{\mathrm{e}}+\dot{\mathrm{p}}_{\mathrm{T}, \mathrm{F}}-\dot{\mathrm{p}}_{\mathrm{T}, \mathrm{H}}-\left(\left(1-\sigma_{\mathrm{H}}\right)\left(\frac{\beta}{\alpha} \dot{\mathrm{a}}_{\mathrm{T}, \mathrm{H}}-\dot{\mathrm{a}}_{\mathrm{N}, \mathrm{H}}\right)-\left(1-\sigma_{\mathrm{F}}\right)\left(\frac{\vartheta}{\gamma} \dot{\mathrm{a}}_{\mathrm{T}, \mathrm{F}}-\dot{\mathrm{a}}_{\mathrm{N}, \mathrm{F}}\right)\right)
$$

In our model, equation (9) is the most general formulation of the B-S effect, which states that, ceteris paribus, to the extent that dual productivity (i.e. excess productivity growth in the traded vs. the non-traded sector) at home is higher than in the foreign country, the real exchange rate will appreciate in real terms $(\dot{\mathrm{q}}<0)$.

The B-S effect determines a real exchange rate appreciation but, in theory, no competitiveness loss, since traded goods prices are set internationally and wages in the traded goods sector grow in step with productivity. In other terms, as long as relative purchasing power parity holds for traded goods, the process of real and nominal convergence occur while keeping the international accounts balanced.

Equations (5) and (6) have been estimated by the most recent literature on the B-S effect, respectively, in the following forms ${ }^{7}$ :

$$
\dot{\mathrm{p}}_{\mathrm{N}}-\dot{\mathrm{p}}_{\mathrm{T}}=\delta_{0}+\delta_{1}\left(\dot{\mathrm{a}}_{\mathrm{T}}-\dot{\mathrm{a}}_{\mathrm{N}}\right)+\varepsilon
$$

\footnotetext{
${ }^{7}$ See Egert (2002), Egert et al.(2003) and Klau and Mihaljek (2004), among others.
} 


$$
\left(\dot{\mathrm{p}}_{\mathrm{N}}-\dot{\mathrm{p}}_{\mathrm{N}}^{*}\right)-\left(\dot{\mathrm{p}}_{\mathrm{T}}-\dot{\mathrm{p}}_{\mathrm{T}}^{*}\right)=\delta_{0}+\delta_{1}\left(\dot{\mathrm{a}}_{\mathrm{T}}-\dot{\mathrm{a}}_{\mathrm{N}}\right)+\delta_{2}\left(\dot{\mathrm{a}}_{\mathrm{T}}^{*}-\dot{\mathrm{a}}_{\mathrm{N}}^{*}\right)+\varepsilon
$$

where we now use an asterisk to denote the foreign (i.e. "rich") country variables and, a priori, we expect $\delta_{1}>0$ and $\delta_{2}<0$.

In general, as confirmed by the evidence on the Penn effect, the price level index should be expected to increase with real GDP per capita. For instance in 2007 - the last year before the crisis- the correlation between the two series in the EU-27 was 0.87 . Thus we should expect that over time price convergence should go in parallel with real catching up. In addition, as argued in the introduction, we might also expect that euro adoption would accelerate the rate of price convergence. Even if we assumed that prices of traded goods were dominated by the law of one price, euro adoption might make prices of non-tradable goods and services more comparable across countries. In this respect, Sturm et al. (2009) show that the $\beta$ convergence of prices in the EU since the creation of the EMU was faster within EMU countries. Moreover, they show that the rate of convergence in the price of non-tradables has increased after the introduction of the euro, both for EMU and non-EMU countries, although the speed of convergence is significantly higher for the former group.

Assuming, for simplicity, that we only had two different exchange rate regimes, fixed and flexible, to estimate the role of adopting the euro or otherwise fixing the exchange rate, we could in principle re-write equation (11) as:

$$
\begin{gathered}
\left(\dot{\mathrm{p}}_{\mathrm{N}}-\dot{\mathrm{p}}_{\mathrm{T}}\right)-\left(\dot{\mathrm{p}}_{\mathrm{N}}^{*}-\dot{\mathrm{p}}_{\mathrm{T}}^{*}\right)=\mu_{\mathrm{i}}+\varphi_{0} \mathrm{D}_{\mathrm{R}}+\varphi_{1}\left(\dot{\mathrm{a}}_{\mathrm{T}}-\dot{\mathrm{a}}_{\mathrm{N}}\right)+\varphi_{2}\left(\dot{\mathrm{a}}_{\mathrm{T}}^{*}-\dot{\mathrm{a}}_{\mathrm{N}}^{*}\right)+\varphi_{3} \mathrm{D}_{\mathrm{R}} * \\
\quad\left(\dot{\mathrm{a}}_{\mathrm{T}}-\dot{\mathrm{a}}_{\mathrm{N}}\right)+\varphi_{4} \mathrm{D}_{\mathrm{R}} *\left(\dot{\mathrm{a}}_{\mathrm{T}}^{*}-\dot{\mathrm{a}}_{\mathrm{N}}^{*}\right)+\varepsilon
\end{gathered}
$$

where $D_{R}$ is a dummy variable which is equal to 1 if the regime is fixed, or the country has adopted the euro, and zero otherwise. Indeed, empirical studies analyzing the impact of the exchange rate regime on macroeconomic performance often employ exchange rate dummies in inflation or growth equations, where the coefficient of the exchange rate regime dummy is interpreted to reveal the effect of the regime on the dependent variable. However, equation (12) embodies two different models, one for each exchange rate regime, and it will require a particular estimation procedure, which we explain in section 3 .

\section{The empirical approach}

Equation (12) in Section 2 generates two econometric problems. First, the choice of the exchange rate regime may be endogenous, as it will in general depend on a country's economic fundamentals. Thus, $\mathrm{D}_{\mathrm{R}}$ will be presumably correlated with the error term, $\varepsilon$. Second, there is a related sample selection problem, as in fact equation (12) embodies two different models, one for each regime. In fact, the exchange rate regime should not only affect the constant, but at the time of the 
regime switch also the coefficients associated with the dual productivity growth change; put it another way, we have a different model for each regime if $\varphi_{0}, \varphi_{3}$ and/or $\varphi_{4}$ are different from zero. As countries do not choose their exchange rate regimes randomly, this choice hinges on a set of fundamentals, which, in turn, affects macroeconomic outcomes. Moreover, for some countries we can only observe one of the regimes, either fixed or flexible. For these reasons, it is not correct to estimate the equation separately for the different regimes and then test for equality of coefficients. Thus, neither using 2SLS nor estimating two separate equations (one for each regime) would properly address the sample selection process.

On the other hand, by properly addressing the sample selection problem we may at the same time solve the endogeneity issue relate to the choice of the exchange rate regime. Following the solution proposed by Domaç et al. (2003), we assume a constant covariance between the error term in equation (12) and the normally distributed random variable whose realization determines the exchange rate regime. We may thus estimate equation (12) using a switching regression model, which allows us to endogenize the choice of the exchange rate regime, so that the parameters of (12) are allowed to be different across regimes, and being in a fixed or flexible exchange rate regime depends on the country's fundamentals.

Consider the regime dummy $D_{R}$. This is set equal to 1 if a country has a fixed exchange rate regime, or to 0 otherwise. Now the value of $D_{R}$ will depend on a latent variable $D_{R}^{o}$ :

$\left\{\begin{array}{lll}D_{R}=1 & \text { if } & D_{R}^{o}>0 \\ D_{R}=0 & \text { if } & D_{R}^{o} \leq 0\end{array}\right.$

In turn, the latent variable describes the willingness to adopt a fixed rather than a flexible exchange rate regime. Therefore, it is defined by

$$
D_{R, i t}^{o}=\mathrm{Z}_{i t} \Gamma+\epsilon_{i t}
$$

Where $\mathrm{Z}$ is a column vector including all variables which affect the choice of the exchange rate regime, including a constant, and $\Gamma$ are the coefficients. Consequently, our empirical model will be the following:

$$
\left\{\begin{array}{lll}
\mathrm{Y}_{\mathrm{it}}=\mathrm{X}_{\mathrm{it}} \mathrm{B}_{1, \mathrm{it}}+\mathrm{u}_{1, \mathrm{it}} & \text { if } \quad \mathrm{D}_{\mathrm{R}}^{\mathrm{o}}<\mathrm{Z}_{\mathrm{it}} \Gamma \\
\mathrm{Y}_{\mathrm{it}}=\mathrm{X}_{\mathrm{it}} \mathrm{B}_{2, \mathrm{it}}+\mathrm{u}_{2, \mathrm{it}} & \text { if } \quad \mathrm{D}_{\mathrm{R}}^{\mathrm{o}}<\mathrm{Z}_{\mathrm{it}} \Gamma
\end{array}\right.
$$

Where: $\quad \mathrm{Y}_{\mathrm{it}}=\left(\mathrm{p}_{\mathrm{N}, \mathrm{it}}-\mathrm{p}_{\mathrm{T}, \mathrm{it}}\right)-\left(\mathrm{p}_{\mathrm{N}, \mathrm{it}}^{*}-\mathrm{p}_{\mathrm{T}, \mathrm{it}}^{*}\right)$;

$$
\mathrm{X}_{\mathrm{it}}=\left[\begin{array}{c}
1 \\
\dot{\mathrm{a}}_{\mathrm{T}}-\dot{\mathrm{a}}_{\mathrm{N}} \\
\dot{\mathrm{a}}_{\mathrm{T}}^{*}-\dot{\mathrm{a}}_{\mathrm{N}}^{*}
\end{array}\right] \text {. }
$$


As discussed by Domaç et al. (2003), while we cannot observe the latent variable, we observe its realization, the dummy variable $D_{R}$. Thus, we can proceed in two steps: first estimate $\Gamma$ using a probit and then use it in a second step to estimate model (13).

The proposed approach amounts to a two-step Heckman (1979) procedure to correct for the sample selection bias, and therefore we need to include the Inverse Mills Ratio resulting from the probit estimation as a regressor in the regressions in (13). Moreover, since the IMR's are estimated rather than observed variables, the standard errors will not be correct, and they must be bootstrapped ${ }^{8}$.

\section{The data}

Our focus on catching up countries among the group of EU members and candidates, chosen with a threshold equal to $75 \%$ of average GDP per capita in the EU 15 in 1998, results in an unbalanced sample of the following 14 countries: Bulgaria, Cyprus, Czech Republic, Estonia, Greece, Hungary, Latvia, Lithuania, Poland, Portugal, Romania, Slovak Republic, Slovenia, Turkey. ${ }^{9}$

The "foreign country" in our analysis is the euro area. More specifically, since Greece and Portugal were in the euro area since its creation, we created a "core" euro area which includes Austria, Belgium, Finland, France, Germany, Italy, Netherlands and Spain ${ }^{10}$.

We focus on the period from 1998:1 until 2011:4. Price and productivity data are from Eurostat and, in the case of Turkey, also national sources. Following the literature on the B-S effect, we use the price index for manufactured goods as a proxy for $p_{T}$, and the price of services as a proxy for $p_{N}$. This choice of proxies is of course objectionable, on the twin grounds that not all manufactured goods are tradable while an increasing number of services is, and that the distinction

\footnotetext{
${ }^{8}$ We therefore follow the approach of Domaç et al. (2003) rather than a panel sample selection model such as those suggested by Wooldridge (1995) and Kyriazidou (1997), as the latter are only appropriate for micro panels (with large N, small T). In particular, Kyriazidou's (1997) panel sample selection method is not consistent with small $\mathrm{N}$.

9 The choice of the GDP threshold is consistent with the definition of "converging regions" in the EU regional policy (although the term of comparison for the policy is currently the EU-27). In 1998, the catching up country with the highest GDP per capita (in PPS) was Cyprus, with 74\% of EU-15 average. Bulgaria and Romania were the countries with the lowest GDP pc $(23.5 \%)$. To ensure data homogeneity within the sample, and in particular to avoid problems related to the non-availability of the data, we excluded Serbia, Croatia and FYROM (Former Yugoslav Republic of Macedonia); we excluded also Malta as the small size of its economy makes it less relevant for our analysis.

10 This leaves out Luxembourg and Ireland, due to data availability issues. To calculate price indices of the "core" euro area, we used country data and weighted them using the weights provided by Eurostat.
} 
between services and manufacturing is by itself imprecise. ${ }^{11}$ However, it is almost impossible - to our knowledge - to achieve a more precise identification of the tradable potential of each sector's production, and thus we stay with the distinction which has been traditionally maintained in the literature. ${ }^{12}$ In its defense, we observe that, even if the distinction tradables/non tradables does not coincide with that between manufactured goods and services, nevertheless in general the tradable potential of goods is considerably higher than that of services.

Productivity is defined as gross value added per hour worked. Due to lack of data on thousands of hours worked for Greece and Turkey, we used thousands of workers. $^{13}$

An important issue to deal with is how to classify exchange rate regimes. In principle, there are two alternatives: de jure and de facto classification. In the former case, we classify regimes based on what the Central Bank declares to be the official exchange rate regime. The problem with this classification is that it may lead to a mistake when a Central Bank pursues an exchange rate policy which is inconsistent with the official regime. Indeed this happens quite frequently, as documented by Calvo and Reinhart (2002), whose work opened the path to a wide strand of literature aimed at estimating de facto as opposed to de jure exchange rate regimes (see, for example, Reinhart and Rogoff, 2004; Levy Yeyati and Sturzenegger, 2005; Frankel and Wei, 2008). More precisely, it is common for Central Banks to adopt a de facto exchange rate regime which is stricter than the official regime so that de jure floaters actually frequently intervene to stabilize the nominal exchange rate, a behavior that Calvo and Reinhart (2002) call "fear of floating". On the other hand, however, the volatility of the exchange rate per se cannot be the only indicator to discern whether a country has "fear of floating". Nominal exchange rate volatility may be low due to the absence of large shocks, or because the business cycle of the countries considered reaches a higher degree of synchronization, i.e. stability of the exchange rate may be, in this sense, endogenous.

\section{[ Insert Table 1 here ]}

\footnotetext{
11 See Christensen (2013), who concludes that "The increasing complexity of production, inertia in changes to statistical systems and the increasing integration of manufacturing products and services are some of the primary and interrelated explanations for this lack of precision". In addition, as Nordas and Kim (2013) observe, the competitiveness of services in also a key ingredient for manufacturing competitiveness.

${ }^{12}$ Sturm et al. (2009) study the convergence of prices among 18 European countries using the data for 224 product groups. However their data cover only the period between 1995 and 2005 and cannot be matched with data on trade openness.

13 Using thousands of hours worked to define employment is preferable because this indicator is not affected by changes in the importance of part-time jobs in the economy. However, in Greece and Turkey there was not a significant change in the ratio of part-time contracts over the total.
} 
Table 1 reports the countries and corresponding exchange rate regimes over the selected sample period. Regimes are classified using a mixed de jure - de facto classification scheme adapted from Reinhart and Rogoff (2004). In particular, we take into account the de jure regime as a starting point; thus, we classify the country as "EMU" if it is a member of the Monetary Union; "Peg" if it has a currency board; "Managed Float" if it declared any limited flexibility regime: fluctuation bands, crawling bands, crawling pegs; and "Inflation Targeting" when the Central Bank's official monetary policy objective is price stability and an explicit target for the inflation rate has been stated. However, in the case of de jure managed floats, if the average monthly percentage change of the bilateral exchange rate vis à vis the euro has remained within a $\pm 1 \%$ band over a 5 -year rolling window, we classify it as a de facto peg. Finally, as in Reinhart and Rogoff (2004), we classify a regime as "freely falling" when inflation exceeds $40 \%$ and/or in the 6 months following an exchange rate crisis. Due to the very limited number of observations for this latter regime, we will not include them in the empirical analysis.

Our empirical analysis will compare, however, only two alternatives: fixed or flexible. The former includes pegs and membership of the EMU, and the latter includes inflation targeting and managed float. In fact, within our sample, the four regimes included in Table 1 are pairwise hard to distinguish from each other, as "Peg" regimes in our dataset have been very hard pegs (i.e. Currency Boards and/or two-year ERM II membership anticipating the entry to EMU with no change in the nominal exchange rate); on the other hand, Inflation Targeters have, in many occasions, engaged in foreign exchange intervention to stabilize the home currency. ${ }^{14}$ In practice, this makes Inflation Targeting regimes observationally equivalent to a de facto managed float. This leave us to focus on only two regimes, which we expect to behave differently from one another. This choice is supported by a preliminary analysis. ${ }^{15}$

\section{The Choice of the Exchange Rate Regime}

As stated above, the choice of the exchange rate regime will depend on macroeconomic factors which affect the relative inflation differential and are left in the error term of the regression equation. In this section, we model how countries self-select in a fixed or a flexible exchange rate regime.

\footnotetext{
14 One example was the National Bank of Hungary which openly intervened in the FOREX markets to stabilize the exchange rate of the Fiorint in November 2003.

15 To validate the choice of focusing on two regimes only, in a preliminary analysis, we modeled the choice of the exchange regime (following the same procedure as described below, in section 4) using an ordered probit as a "regime" variable, with regimes ordered from the most rigid to the most flexible. This analysis confirmed that EMU membership and Peg, on the one hand, and Managed Float and Inflation Targeting on the other are observationally equivalent regimes.
} 
Based on the theory of the Optimal Currency Area (OCA) and on previous research (Heller 1978; Holden et al. 1979 and 1981; Edwards 2006; Levy Yeyati et al. 2010) we may classify the variables that affect the choice of the exchange rate regime in two broad groups: economic and political. The first group includes: ${ }^{16}$

a. Degree of Trade Openness. As suggested by the OCA theory, the more a country is more open to international trade, the more it will be averse to an excessive volatility of the exchange rate and thus also more likely to adopt a fixed exchange rate. We define the degree of trade openness as:

$$
O P E N N E S S_{i}=\frac{I M P_{i}+E X P_{i}}{G D P_{i}}
$$

b. Economic Size of the Country. The larger a country's size, the less it will find it beneficial or attractive to fix or manage the exchange rate. We proxy economic size by the (log) GDP level.

The second group of variables is introduced on the basis of the fact that the political environment also plays a role in the choice of the exchange rate regime:

c. Years since EU membership. We expect that the longer a country has been a member of the European Union, the more it should be willing to fix the exchange rate or adopt the euro. This also because, with the exception of countries with an opt-out clause, adoption of the euro is an eventual requirement of EU membership.

d. Effectiveness score. This variable, taken from the Polity IV "State Fragility Index" (SFI) Database, measures Political Effectiveness (Regime durability, Current Leader Years in office, Total Coup events), Economic Effectiveness (GDP per Capita) and Social Effectiveness (Human Capital Development). It takes integer values from 0 to 9 , where 0 equals maximum effectiveness. A country with a low effectiveness score should be more willing to give up its sovereignty over the exchange rate, or less capable to keep a flexible exchange rate without incurring into the risk of large fluctuations, or to establish a credible inflation targeting regime. On the contrary, for a country having, say, a credible and independent Central Bank, the costs related to giving up monetary policy independence, in terms of risk of

\footnotetext{
16 Other variables that have been suggested in the literature modeling the choice of the exchange rate regime are the product and the geographical concentration of trade. For both variables, a higher concentration should lead to a stronger preference for fixing. In our case, we found that the estimated coefficient for geographical concentration (measured as the share of total trade within the EMU) is never significant. For product concentration, we estimated a model including an Hirschmann-Herfindahl Index (HHI) of product concentration; the fit of this model, however, is worse with respect to that of the model including the degree of openness. In addition, we have data for this variable only from 1999 or 2000 (and not for Turkey). Since also on a priori grounds we prefer to use the degree of openness, we decided to use only this variable (as described in the text) and to neglect the use of the HHI index.
} 
asymmetric shocks, may outweigh the benefits coming from joining a solid and credible monetary union.

Given the dummy variable FIX, equal to 0 when the country has a managed float or inflation targeting regime, and 1 in case of peg or EMU membership, we model the choice of the exchange rate regime as:

FIX $_{\text {it }}=\gamma_{1}$ OPENNESS $_{\text {it }}+\gamma_{2}$ LogGDP $_{\text {it }}+\gamma_{3}$ EFFECTIVENESS $_{i t}+\gamma_{4}$ YEARS $_{i t}+\varepsilon_{i t}$

where, given our previous discussion, we expect $\gamma_{1}>0 ; \gamma_{2}<0 ; \gamma_{3}>0 ; \gamma_{4}>0$.

\section{[ Insert Table 2 here ]}

Table 2 reports the results of the probit estimation of Equation (14). We can look at the percentage of correctly predicted outcomes as a rough measure of the goodness of fit. This is calculated as follows:

$$
p c p=\frac{N_{1 \mid 1}+N_{0 \mid 0}}{N_{1}+N_{0}}
$$

where $\mathrm{N}_{1 \mid 1}$ is the number of cases where the model predicts $F I X=1$ and it is indeed $1, \mathrm{~N}_{0 \mid 0}$ is the number of cases where the model predicts FIX=0 and it is indeed $0, N_{1}$ is the total number of cases where $F I X=1$ and $N_{0}$ is the total number of cases where $F I X=0$. From our estimates $p c p$ is equal to $73.3 \%$, which shows that the model is fairly good in explaining why a country finds itself in a fixed or flexible regime. Moreover, looking at Table 2, we note that OPENNESS and YEARS have a positive coefficient (the more open to trade, and the more years in the EU, the higher the probability to FIX); LogGDP has a negative sign (the lower is GDP, i.e. the "smaller" the country, the higher the probability to FIX). Finally, a higher value of EFFECTIVENESS (which measures a lower political and economic effectiveness), as expected, has a positive sign: the higher the score, the higher the probability to fix. These results are consistent with those of Levy Yeyati, Sturzenegger and Reggio (2010), who found that the probability of pegging the exchange rate is negatively correlated with the quality of institutions.

\section{The B-S Effect across Exchange Rate Regimes}

As anticipated in Section 3, in the second step we estimate the fundamental B-S regression (as specified in (12)) for each regime, correcting for the sample selection bias by including the Inverse Mills Ratio calculated from the estimation of equation (14) and bootstrapping standard errors.

Before introducing the two-stage estimation, as a simple exercise we estimate the modified B-S equation separately for each regime, i.e. estimate equation (12): 


$$
\begin{aligned}
\left(\dot{p}_{N}-\dot{p}_{T}\right)- & \left(\dot{p}_{N}^{*}-\dot{p}_{T}^{*}\right) \\
& =\mu_{i}+\varphi_{0} \boldsymbol{D}_{\boldsymbol{R}}+\varphi_{1}\left(\dot{a}_{T}-\dot{a}_{N}\right)+\varphi_{2}\left(\dot{a}_{T}^{*}-\dot{a}_{N}^{*}\right)+\varphi_{3} \boldsymbol{D}_{\boldsymbol{R}} *\left(\dot{a}_{T}-\dot{a}_{N}\right) \\
& +\varphi_{4} \boldsymbol{D}_{\boldsymbol{R}} *\left(\dot{a}_{T}^{*}-\dot{a}_{N}^{*}\right)+\varepsilon
\end{aligned}
$$

We denote this approach as "naïve" since, by ignoring the endogeneity of $\mathbf{D}_{\mathbf{R}}$, it fails to capture the causal link between macroeconomic fundamentals and the exchange rate regime. Hence these estimates suffer from a sample selection problem. Nevertheless, as a preliminary exercise it might still be helpful to identify some ways in which the different exchange rate regimes have an impact on structural inflation. We report the results of this naïve estimation in Table 3 , where the FIX regime is taken as the baseline. ${ }^{17}$

\section{[ Insert Table 3 here ]}

First we note that, as expected, in the base regime the home productivity growth differential has a positive and significant coefficient and the foreign productivity growth differential has a negative coefficient, which is what the B-S hypothesis predicts. Moreover, while the coefficient on the interaction term relative to the home productivity differential $\left(\dot{a}_{T}-\dot{a}_{N}\right) *$ FIX is significantly different from zero, this is not the case for the coefficient on the interaction term relative to the productivity differential in the foreign country, $\left(\dot{a}_{T}^{*}-\dot{a}_{N}^{*}\right) * F I X$, which suggests that this effect is equal across regimes. This makes sense: remember from equation

(6) that $\varphi_{2}$ is proportional to the output share of labor in the non-traded sector relative to the traded sector in the foreign country, thus we do not expect that it should change across exchange rate regimes of the home country. However, the significance of the interaction term for the home productivity differential implies that a productivity growth differential of $1 \%$ is associated with a change in the relative terms of trade of $0.08 \%$ when the exchange rate regime is (more or less) flexible, but is much stronger, at $0.175 \%$, when the exchange rate is fixed. In other terms, for a given productivity growth differential in favor of the traded goods sector, the growth in non-traded goods prices is more than double in a fixed versus flexible exchange rate regime. This "naïve" estimation suggests that a stricter exchange rate regime is associated with a larger size of the B-S effect. However, as we remarked earlier on that these estimates cannot take into account the endogeneity of the chosen regime, we now move on to discuss the results of adopting the switching regression approach, as described in Section 3.

\section{[ Insert Table 4 here ]}

\footnotetext{
17 In these estimates, accounting for the role of the exchange rate regime boils down to checking the significance of the coefficients of the two interaction terms. If they are not significantly different from zero, then the choice of the exchange rate regime would have no impact on the rate of nominal convergence, i.e. it would not affect the rate of B-S convergence.
} 
Table 4 reports the results of the switching regression model ${ }^{18},{ }^{19}$. The significance of the Inverse Mills Ratio (IMR) in the Flexible model means that indeed there is a significant sample selection.

However, from a qualitative point of view, the results obtained using the naïve approach are confirmed also here: convergence à la B-S is faster for countries that have pegged their exchange rate or have joined the EMU, and significantly so (at $5 \%$ ), while the coefficient of the foreign productivity differential is not significantly different between the two regimes.

These results imply that ignoring the role of the exchange rate regime in the estimation of the B-S effect leaves aside one element that significantly affects the process of price convergence. During the last decade, the economic literature has demonstrated that the B-S Effect can only explain a small part of the excess inflation experienced by Central and Eastern European Countries. Egert (2007) pointed out some additional factors explaining price convergence, in particular the change in the composition of the consumption basket towards higher-quality goods, different economic structures. With our analysis, we provide an additional element that had so far not been considered by the literature and show that, for a given degree of productivity convergence, price convergence is faster if the exchange rate regime is fixed.

This does not necessarily imply that adopting the euro or pegging the exchange rate when the catching-up process is still under way would imply a loss of competitiveness, given that what matters for competitiveness is only the traded goods inflation differential, $\dot{p}_{T}-\dot{p}_{T}^{*}$. As we remarked in section 2 , we would observe a loss of competitiveness only to the extent that the higher inflation in the non-traded sector would induce a faster growth of prices in the traded sector, relative to that of the benchmark competitors. ${ }^{20}$ However, since non-traded goods are part of the CPI, our results do imply that, other things equal, adoption of a strict peg or of the euro may determine higher CPI inflation for a catching-up country. ${ }^{21}$

\footnotetext{
18 The reported standard errors are robust to heteroskedasticity. We tested for residual autocorrelation and the null of no AR(1) could not be rejected at any significance level using the DW test proposed by Drukker (2003).

${ }^{19}$ All series were tested for the presence of a unit root using Pesaran CADF test and they came out to be I $(0)$.

20 This aspect is examined in detail in a parallel research, see D'Adamo and Rovelli (2013).

21 Moreover, to the extent that non-traded goods are used as inputs for traded goods, this may have second-round effects on traded goods prices and, finally, on competitiveness. However, this goes beyond the scope of the present paper.
} 


\section{Exchange rate regimes, dual inflation differential and competitiveness}

Our results so far point to the fact that, for any given dual productivity differential, a higher dual inflation differential is generally observed in those countries that have opted for a fixed exchange rate regime or for membership in the euro area, relative to those countries that opted for a flexible regime or managed float.

The crucial question is whether this does also imply a loss of competitiveness for the former countries. More generally, is it possible to find a relationship between the exchange rate regime and competitiveness? As we discussed in the introduction, for a country which is still in the process of convergence, the perceived stability guaranteed by membership of the euro area, or by setting up a hard peg or a currency board, may lead to large capital inflows and optimismdriven booms, and this may indeed have been the case for the euro area periphery and the Baltics ${ }^{22}$. Such economic booms were driven by domestic consumption which, on the one hand, determined a worsening of the current account and, on the other hand, pushed prices and wages up, damaging the country's competitiveness and thus contributing to further worsening of the current account.

On the basis of this reasoning, we look at competitiveness using two variables: (i) the export market share (henceforth EMS), i.e. a country's total exports as a share of world exports, and (ii) the ratio of the current account balance to GDP (CAB). While the latter is strictly not an indicator of competitiveness, as its evolution over time is influenced by internal as well as by external shocks to aggregate demand and supply, it is also true that a deterioration of competitiveness invariably shows up as a worsening of the CAB. We thus shall observe also the evolution of this variable, in addition and as a robustness check to focusing on the evolution of the EMS.

Figures 2 and 3 below show the evolution of these two variables during our sample period. The EMS of Cyprus, Portugal and Greece have declined throughout the last decade, and also that of Slovenia since 2007. They have instead been generally increasing for the rest of the CEEC and Turkey. As for the CAB, it has been generally deteriorating for most countries in the picture until 2007, and has only been improving afterwards, with the explosion of the Great Recession.

\section{[ Insert Figures 2 and 3 here ]}

To obtain a clearer picture and analyze the issue more formally, we then regress the competitiveness measures on the dual inflation differential and the exchange

22 See Kang and Shambaugh (2013). 
rate regime, including country and year fixed effects ${ }^{23}$. Thus, although we are not estimating a model of the determinants of a country's competitiveness, we can disentangle the relationship between the exchange rate regime, the dual inflation differential and competitiveness, while controlling for year effects which may be important (for example, the outbreak of the Great Recession, entrance into the EU, and the signing of international trade agreements may have had important independent effects on the EMS of many catching up economies).

Since the dual inflation differential may affect exports with some delay, we use its lagged value as an explanatory variable. For the exchange rate regime, we use two alternative definitions: (i) ERR: the Exchange Rate Regime index by Reinhart and Rogoff (2004), going from 1 (monetary union) to 6 (freely floating); (ii) fix: the fixed regime dummy as introduced in our paper, i.e. fix $=1$ if the regime is either membership in the EMU or a de facto peg, and 0 otherwise.

Tables 5 and 6 report the results for the EMS and the CAB, respectively. We ran different regressions both for the whole sample (until 2011) and until 2008. We will rely mostly on the shorter sample, as we expect post-2008 instability and also the results to depend heavily, after 2008 , on the adoption of austerity policies and the so-called internal devaluations.

\section{[ Insert Tables 5 and 6 here ]}

In the equations for EMS, we notice having adopted a fixed ER is associated with an EMS about 5\% lower (column 1). But especially we note that this effect is reinforced for countries that exhibit a higher dual inflation (col. 2), while there is no such effect for the generality of countries (col. 3). These effects are confirmed for the longer sample, although the F-test of post-sample stability is rejected. ${ }^{24}$

For the $\mathrm{CAB}$, we find that the change in the relative terms of trade, i.e. the (lagged) dual inflation differential has a negative and significant impact. An increase by 1 p.p. of the dual inflation differential leads to a worsening of the CAB by $0.18-0.20$ p.p. In addition, we also observe regimes which are more flexible tend to be associated with better $\mathrm{CAB}$, ceteris paribus, although this effect is significant only when using ERR. Again, the F test for stability rejects stability when we add the post-crisis sample, although in this case only at $5 \%$.

Overall these results are suggestive that a worsening of the dual inflation differential may especially endanger competitiveness in countries that have

\footnotetext{
${ }^{23}$ Data for the empirical analysis in this section are annual, since EMS is only available on an annual basis, and so is the $\mathrm{CAB}$ for some of the sample countries during the first few years we consider. For both variables, the source is Eurostat.

24 The performed test statistic is calculated as $\frac{\left[R S S\left(n_{1}+n_{2}\right)-R S S\left(n_{1}\right)\right] / n_{2}}{R S S\left(n_{1}\right) /\left(n_{1}-k\right)}$, where RSS is the residual sum of squares, $n_{1}$ is the sample 1998-2008, $n_{2}$ is the sample 2009-2011 and $k$ is the number of estimated coefficients. See Kennedy (2009).
} 
adopted a fixed exchange rate regime, presumably as the latter does not allow of restoring competitiveness through a re-adjustment of the nominal exchange rate.

\section{Conclusions and policy implications}

In this paper we have argued that the adoption of a fixed exchange rate may significantly amplify the so-called "External Balassa-Samuelson Effect". The main supporting evidence is that, in a group of 14 "catching up" European countries, in which we have observed 8 cases of adoption of (or transition to) a fixed exchange rate, the impact of the domestic productivity growth differential (between the traded and non-traded goods sectors) on the dual inflation differential (i.e. the relative inflation differential between the prices of non-traded and traded goods) is more than double in the case of a fixed exchange rate, relative to a floating rate regime.

In the last decade, the literature on the Balassa-Samuelson Effect in Eastern Europe has shown that the B-S effect has a limited role in explaining the excess inflation experienced by European catching-up countries with respect to the euro area (Egert, Halpern and MacDonald 2006). While other researchers have investigated alternative sources of price level convergence (as in Fischer 2004 and Egert 2007), our purpose was to shed light on the possible role of the choice of the exchange rate regime in this respect.

The choice of the exchange rate regime has been a matter of continued and often very controversial policy debate, especially within the EU and since the introduction of the euro. However, while it has been generally acknowledged that fixing the exchange rate may have the effect of imposing overall inflation "discipline" to a country that joins a low inflation currency area, the implications that this might have for the dual (or "structural") inflation differential have been largely unexplored.

In fact these implications are somewhat paradoxical, as we have found that the adoption of a fixed exchange rate peg or also of the euro will accelerate the path of price convergence, in particular in the non-traded sector. Possibly, one reason for this result is that fixing the exchange rate enhances the comparability across countries also of the prices of non-traded goods and services. Hence, relative inflation (between non-traded and traded goods prices) will be higher for countries that fix the exchange rate with respect to floating countries. As a result, also the aggregate inflation rate, measured by the CPI, will ceteris paribus be higher in those countries - and may actually increase after, and as a consequence of, for instance, euro adoption.

Does this finding have relevant implications? If the dual inflation differential increases after adopting the euro (or pegging the exchange rate to it), then prices 
in the non-traded sector increase more, relative to the traded sector, when productivity increases. Since non-traded goods are part of the CPI, then, even if PPP held for traded goods, a catching up country within a fixed exchange rate arrangement will have higher CPI inflation, other things equal, and will also experience a faster real exchange rate appreciation. However this will not by itself reduce that country's competitiveness, as that would only be affected by changes in the terms of exchange for traded goods. However, two implications are worth noting.

First, if a catching up country fulfils the Maastricht Criteria for euro adoption, including the inflation criterion, and adopts the euro, it may well experience an increase in inflation, due to the dynamic effects that we have described. For this reason, the inflationary "discipline" imposed by the single monetary policy on new members of the euro area may well become ex post less effective, especially if measured in reference to non-traded goods. This in turn may reduce the local effectiveness of monetary policy, as the local real rate of interest will be comparatively lower.

Second, the conclusion that higher inflation in the non-traded sector will not harm a country's competitiveness is true only to the point that higher inflation does not extend also to the traded sector. But the opposite result is also plausible, as the accelerated growth of prices and wages in the non-traded sector may well extend to, or "contaminate" wages and prices in the traded sector, prevailing to some extent on the competitive pressures from foreign markets. In this case, a country which has entered into a monetary union or has irrevocably fixed the exchange rate will find itself with no dedicated policy instruments to overcome the loss of international competitiveness. Also, at the same time the urgency to adopt appropriate remedies might no longer be perceived, as the common currency contributes to de-emphasize the warning signals from a worsening current account or a reduced share in the foreign markets. To show the relevance of this "contamination" effect, we documented in section 6 that, in our sample of catching up countries, a fixed ER is approximately associated with a 5\% lower export market share, and that this effect is reinforced for countries that exhibit a higher dual inflation (see Table 5).

These implications may also suggest two normative considerations: first, the "Maastricht inflation criterion" does not provide a robust indicator of a country's suitability for euro adoption, nor a reliable indicator of its post-adoption inflation performance; second, euro adoption or exchange rate fixing by catching-up countries may in some cases be premature and lead to a loss of external competitiveness and to non-responsiveness to the common monetary policy, hence it should not be (possibly, it should not have been?) encouraged. We leave it to others to articulate these points into a positive policy message. 


\section{Acknowledgements}

Gaetano D'Adamo acknowledges the financing support from Spanish MICINN (EC02011-30260-C03-01). We thank Maria Rochina Barrachina, Helena Ferrera Marques, and participants of the XIV Conference on International Economics in Palma de Mallorca, for their enlightening comments.

\section{References}

Balassa, B. (1964) "The Purchasing-Power Parity Doctrine: a Reappraisal”. Journal of Political Economy 72 (6), pp. 584-96.

Begg, D., Halpern, L., and Wyplosz, C. (1999) “Monetary and exchange rate policies, EMU and Central and Eastern Europe". Forum report on the Economic Policy Initiative No. 5, London: CEPR.

Calvo, G.A., and Reinhart, C.M. (2002) "Fear of Floating”. The Quarterly Journal of Economics 118 (2), pp. 379-407.

Christensen, J.L. (2013) "The ability of current statistical classifications to separate services and manufacturing". Structural Change and Economic Dynamics 26, pp. 4760.

D’Adamo, G., and Rovelli, R. (2013) “Labor market institutions and the response of inflation to macro shocks in the EU: a two-sector analysis". Unpublished.

Domaç, I.; Peters, K., and Y. Yuzefovich (2003) "Does the Exchange Rate Regime matter for Inflation? Evidence from Transition Economies". Central Bank of Turkey Working Paper n.304.

Dobrinsky, R. (2006) "Catch-up inflation and nominal convergence: the balancing act for new EU entrants”. Economic Systems 30 (4) pp. 424-442.

Drukker, D. M. (2003) "Testing for serial correlation in linear panel-data models". Stata Journal 3 (2), pp. 168-177.

Edwards, S. (1996) "The determinants of the choice between fixed and flexibleexchange rate regimes". NBER Working Paper, No. 5756.

Egert, B. (2002) "Investigating the Balassa-Samuelson hypothesis in the transition". Economics of Transition 10 (2), pp. 273-309.

Égert, B. (2007) "Real Convergence, Price Level Convergence and Inflation in Europe". Bruegel Working Paper 267, Brussels: Bruegel. 
Egert, B. (2010) "Catching Up and Inflation in Europe: Balassa-Samuelson, Engel's Law and other culprits". OECD Economics Department Working Paper N $^{\circ} 792$, OECD Publishing.

Egert, B., Drine, I., Lommatzsch, K., and Rault, C. (2003) "The Balassa-Samuelson effect in Central and Eastern Europe: myth or reality?". Journal of Comparative Economics 31 (3), pp. 552-72.

Egert, B., Halpern, L., and MacDonald, R. (2006) "Equilibrium exchange rates in transition economies: taking stock of the issues". Journal of Economic Surveys 20 (2), pp. 257-324.

Egert, B., and Podpiera, J. (2008) "Structural Inflation and Real Exchange Rate Appreciation in Visegrad-4 countries: Balassa-Samuelson or something else?". CEPR Policy Insight No. 20, London: CEPR.

Fischer, C. (2004) "Real Currency Appreciation in Accession Countries: BalassaSamuelson and Investment Demand". Review of World Economics 140 (2), pp. 179210.

Frankel, J., and Wei, S.J. (2008) "Estimation of de facto exchange rate regimes: synthesis of the techniques for inferring flexibility and basket weights". IMF Staff Papers 55(3).

Froot, K., and Rogoff, K. (1995) "Perspectives on PPP and Long-Run Real Exchange Rates" in G. Grossman and K. Rogoff (eds.) Handbook of International Economics, Vol. 3, Amsterdam: Elsevier.

Ghosh, A.R., Ostry, J., Gulde, A.M., and Wolf, H.C. (1997) "Does the Exchange Rate Regime Matter for Inflation and Growth?". IMF Economic Issues No.2, IMF.

Golinelli, R., and Orsi R. (2002) "Modelling inflation in EU accession countries: The case of the Czech Republic, Hungary and Poland". Eastward Enlargement of the Euro-zone Working Papers, Free University Berlin, Jean Monnet Centre of Excellence.

Heckman, J. (1979) "Sample selection bias as a specification error". Econometrica 47, pp. $153-161$.

Heller, H.R. (1978) "Determinants of exchange rate practices". Journal of Money, Credit and Banking 10, pp. 308-321.

Holden, M., Holden, P., and Suss, E.C. (1979) "The Determinants of Exchange Rate Flexibility: An Empirical Investigation". The Review of Economics and Statistics 61 (3), pp. 327-333. 
Holden, M., Holden, P., and Suss, E.C. (1981) "Policy objectives, country characteristics and the choice of the exchange rate regime". Rivista Internazionale di Scienze Economiche e Commerciali 28, pp. 1001-14.

Ilzetzki, E., Reinhart, C.M., and Rogoff, K.S. (2010) "Exchange Rate Arrangements Entering the 21st Century: Which Anchor Will Hold?". Unpublished.

Kang, J.S., and Shambaugh, J.C. (2013) "The evolution of current account deficits in the Euro Area periphery and the Baltics: Many paths to the same endpoint". IMF Working Paper WP/13/169.

Kasimati, E., and Veraros, N. (2013) "Should Greece adopt a dual-currency regime to resolve its economic crisis?". Journal of Policy Modeling 35, pp. 588-600.

Kennedy, P. (2009) A guide to econometrics. Blackwell Publishing, 6th ed.

Klau, M., and Mihaljek, D. (2004): “The Balassa-Samuelson effect in central Europe: a disaggregated analysis". Comparative Economic Studies 46, pp. 63-94.

Krugman, P. (2013) "Revenge of the Optimum Currency Area". In D. Acemoglu, J. Parker, and M. Woodford (eds.) NBER Macroeconomics Annual 2012, Vol. 27, pp. $439-448$.

Kyriazidou, E. (1997) "Estimation of a Panel Data Sample Selection Model". Econometrica 65 (6), pp. 1335-1364.

Levy-Yeyati, E., and Sturzenegger, F. (2003) "To float or to fix: evidence on the impact of exchange rate regimes on growth". American Economic Review 93 (4), pp. $1173-1193$.

Levy-Yeyati, E., and Sturzenegger, F. (2005) “Deeds vs. Words: classifying exchange rate regimes". European Economic Review 49 (6), pp. 1603 - 1635.

Levy Yeyati, E., Sturzenegger, F., and Reggio, I. (2010) "On the endogeneity of exchange rate regimes”. European Economic Review 54 (2010), pp. 659 - 677.

Nordas, H.K., and Kim, Y. (2013) "The role of services for competitiveness in manufacturing". OECD Trade Policy Papers No. 148, OECD Publishing.

Reinhart, C.M., and Rogoff, K.S. (2004) "The modern history of exchange rate arrangements: a reinterpretation". Quarterly Journal of Economics 119 (1), pp. 1 48.

Samuelson P.A. (1964) "Theoretical Notes on Trade Problems". The Review of Economics and Statistics 46 (2), pp. 145-154.

Sturm, J.E., Fritsche, U., Graff, M., Lamla, M., Lein, S., Nitsch, V., Liechti, D., and Triet, D. (2009) "The euro and prices: changeover-related inflation and price 
convergence in the euro area". European Economy - Economic Papers n. 381, June 2009.

Wooldridge, J.M. (1995) "Selection corrections for panel data models under conditional mean independence assumptions". Journal of Econometrics 68, pp.115132. 


\section{Data Appendix}

\begin{tabular}{|c|c|}
\hline Variable & Definition and Source \\
\hline$\dot{p}_{T}$ & Annual \% change in the HCPI for Goods. Source: Eurostat. \\
\hline$\dot{p}_{N}$ & Annual \% change in the HCPI for Services. Source: Eurostat. \\
\hline$\dot{a}_{T}$ & $\begin{array}{l}\text { Annual \% change in labor productivity in the goods sector, } \\
\text { calculated as gross value added per hour worked. Source: } \\
\text { Eurostat and authors' calculations. }\end{array}$ \\
\hline$\dot{a}_{N}$ & $\begin{array}{l}\text { Annual \% change in labor productivity in the services sector, } \\
\text { calculated as gross value added per hour worked. Source: } \\
\text { Eurostat and authors' calculations. }\end{array}$ \\
\hline$C A B$ & Current Account Balance in \% of GDP. Source: Eurostat. \\
\hline$E M S$ & $\begin{array}{l}\text { Export Market Share, calculated as a country's exports as a share } \\
\text { of world exports. Source: Eurostat. }\end{array}$ \\
\hline$E R R$ & $\begin{array}{l}\text { Exchange Rate Regime Variable, going from } 1 \text { (no separate legal } \\
\text { tender; currency union) to } 5 \text { (freely falling). Source: Ilzetzki, } \\
\text { Reinhart and Rogoff (2010). }\end{array}$ \\
\hline FIX & $\begin{array}{l}\text { Dummy equal to } 1 \text { for countries and periods when the exchange } \\
\text { rate regime in Table } 1 \text { is either Peg or EMU, zero otherwise. }\end{array}$ \\
\hline OPENNESS & Trade openness. See Section 4. Source: Eurostat \\
\hline$G D P$ & Source: Eurostat. \\
\hline YEARS & Years since EU membership. \\
\hline EFFECTIVENESS & $\begin{array}{l}\text { Effectiveness Score. See Section 4. Source: Polity IV, State } \\
\text { Fragility (SFI) Database. }\end{array}$ \\
\hline
\end{tabular}


Table 1. Chronology of Exchange Rate Regimes

\begin{tabular}{|c|c|c|}
\hline \multirow{2}{*}{ Bulgaria } & Q1.1996 - Q3.1997 & Freely Falling \\
\hline & Q4.1997 - Q4.2011 & Peg \\
\hline \multirow{2}{*}{ Cyprus } & Q1.1996-Q4.2007 & Managed Floating \\
\hline & Q1.2008 - Q4.2011 & EMU \\
\hline \multirow{2}{*}{ Czech Republic } & Q1.1996 - Q4.1997 & Managed Floating \\
\hline & Q1.1998 - Q4.2011 & Inflation Targeting \\
\hline \multirow{2}{*}{ Estonia } & Q1.1996 - Q4.2010 & Peg \\
\hline & Q1.2011 - Q4.2011 & EMU \\
\hline Greece & Q1.1996 - Q4.2000 & Managed Floating \\
\hline \multirow{2}{*}{ Hungary } & Q1.1996-Q2.2001 & Managed Floating \\
\hline & Q3.2001 - Q4.2011 & Inflation Targeting \\
\hline Latvia & Q1.1996 - Q4.2011 & Peg \\
\hline Lithuania & Q1.1996 - Q4.2011 & Peg \\
\hline \multirow{2}{*}{ Poland } & Q1.1996 - Q4.1997 & Managed Floating \\
\hline & Q1.1998 - Q4.2011 & Inflation Targeting \\
\hline \multirow{3}{*}{ Portugal } & Q1.1996 - Q4.1998 & Managed Floating \\
\hline & Q1.1999 - Q4.2011 & EMU \\
\hline & Q1.1996 - Q2.2001 & Freely Falling \\
\hline \multirow[t]{2}{*}{ Romania } & Q3.2001 - Q2.2005 & Managed Floating \\
\hline & Q3.2005 - Q4.2011 & Inflation Targeting \\
\hline \multirow{2}{*}{ Slovenia } & Q1.1996 - Q4.2006 & Managed Floating \\
\hline & Q1.2007 - Q4.2011 & EMU \\
\hline \multirow{2}{*}{ Slovakia } & Q1.1996 - Q4.2008 & Managed Floating \\
\hline & Q1.2009-Q4.2011 & EMU \\
\hline \multirow{2}{*}{ Turkey } & Q1.1996 - Q4.2001 & Freely Falling \\
\hline & Q1.2002 - Q4.2011 & Inflation Targeting \\
\hline
\end{tabular}

Source: Adapted from Ilzetzki, Reinhart and Rogoff (2010). 
Table 2. Probit regression, Equation (14)

\begin{tabular}{lcccc} 
& Coefficient & St. Error & P-value & $\begin{array}{c}\text { Marginal } \\
\text { Effect }\end{array}$ \\
\hline OPENNESS & 2.369 & 0.295 & 0.000 & 0.941 \\
LogGDP & -3.766 & 0.410 & 0.000 & 0.347 \\
EFFECTIVENESS & 0.874 & 0.174 & 0.000 & -1.496 \\
YEARS & 0.609 & 0.065 & 0.000 & 0.242 \\
$\left(\dot{a}_{T}-\dot{a}_{N}\right)$ & -0.847 & 1.688 & 0.616 & -0.336 \\
$\left(\dot{a}_{T}^{*}-\dot{a}_{N}^{*}\right)$ & -3.416 & 7.072 & 0.629 & -1.357 \\
Constant & 28.744 & 3.257 & 0.000 & - \\
\hline
\end{tabular}

Legenda: Probit estimation of equation (14). Dependent variable is FIX. See text in Section 4 and Data Appendix for definition of variables. 
Table 3. "Naïve" estimation, Equation (12)

\begin{tabular}{lccc}
\hline & Coefficient & Robust Std. Error & P-Value \\
\hline $\mathrm{M}$ & 0.004 & 0.002 & 0.035 \\
FIX & -0.001 & 0.003 & 0.724 \\
$\left(\dot{a}_{T}-\dot{a}_{N}\right)$ & 0.080 & 0.018 & 0.000 \\
$\left(\dot{a}_{T}-\dot{a}_{N}\right) * F I X$ & 0.095 & 0.046 & 0.039 \\
$\left(\dot{a}_{T}^{*}-\dot{a}_{N}^{*}\right)$ & -0.210 & 0.067 & 0.002 \\
$\left(\dot{a}_{T}^{*}-\dot{a}_{N}^{*}\right) *$ FIX & -0.034 & 0.091 & 0.708 \\
Country Fixed Effects & YES & - & - \\
\hline
\end{tabular}

$\mathrm{N}=633 . \quad \mathrm{R}^{2}: 0.174$

Legenda: OLS estimation of equation (12). Dependent variable is the dual inflation differential. See text and Data Appendix for definition of variables.

Table 4. Balassa-Samuelson effect in fixed and flexible exchange rate regimes

\begin{tabular}{|c|c|c|c|}
\hline & Coefficient & Robust Std. Error & P-Value \\
\hline \multicolumn{4}{|l|}{ Fixed } \\
\hline M & 0.004 & 0.002 & 0.047 \\
\hline$\left(\dot{a}_{T}-\dot{a}_{N}\right)$ & 0.176 & 0.068 & 0.009 \\
\hline$\left(\dot{a}_{T}^{*}-\dot{a}_{N}^{*}\right)$ & -0.238 & 0.051 & 0.000 \\
\hline IMR & -0.002 & 0.008 & 0.841 \\
\hline Country Fixed Effects & YES & - & - \\
\hline $\mathrm{N}=350 . \quad \mathrm{R}^{2}: 0.194$ & & & \\
\hline \multicolumn{4}{|l|}{ Flexible } \\
\hline M & 0.006 & 0.002 & 0.007 \\
\hline$\left(\dot{a}_{T}-\dot{a}_{N}\right)$ & 0.075 & 0.043 & 0.080 \\
\hline$\left(\dot{a}_{T}^{*}-\dot{a}_{N}^{*}\right)$ & -0.217 & 0.052 & 0.000 \\
\hline IMR & -0.010 & 0.005 & 0.042 \\
\hline Country Fixed Effects & YES & - & - \\
\hline \multicolumn{4}{|l|}{$\mathrm{N}=272 . \quad \mathrm{R}^{2}: 0.124$} \\
\hline \multicolumn{2}{|l|}{ Test of coefficient equality } & $\begin{array}{l}\text { Variable } \\
\left(\dot{a}_{T}-\dot{a}_{N}\right) \\
\left(\dot{a}_{T}^{*}-\dot{a}_{N}^{*}\right)\end{array}$ & $\begin{array}{l}\text { Test statistic (p-val.) } \\
4.63(0.032) \\
0.15(0.696)\end{array}$ \\
\hline
\end{tabular}

Legenda: The Table reports the result of the estimation of equations (13), on the basis of the probit estimation of the choice of the exchange rate regime, described in Sect. 4, Table 2. Dependent variable is the dual inflation differential. See text in Sect. 3 for definitions of variables. Standard errors are bootstrapped. Test on coefficient is distributed as $F(1,602)$. 
Table 5. Export Market Share, dual inflation differential and the Exchange Rate Regime

\begin{tabular}{lllllll}
\multicolumn{5}{c}{ Sample until 2008 } & \multicolumn{5}{l}{ Whole Sample } \\
\hline & 1 & 2 & 3 & 1 & 2 & 3 \\
\hline$\left(\dot{p}_{N}-\dot{p}_{T}\right)-\left(\dot{p}_{N}^{*}-\dot{p}_{T}^{*}\right)_{t-1}$ & & & 0.003 & & & $0.004^{* *}$ \\
$F I X$ & $-0.040^{* *}$ & $-0.048^{* *}$ & $-0.053^{* *}$ & $-0.047^{* *}$ & $-0.056^{* * *}$ & $-0.063^{* * *}$ \\
$\left(\dot{p}_{N}-\dot{p}_{T}\right)-\left(\dot{p}_{N}^{*}-\dot{p}_{T}^{*}\right)_{t-1}$ & & 0.003 & $-0.005^{* *}$ & & -0.003 & $-0.007^{* * *}$ \\
& & & & & & \\
Cons & $0.287^{* * *}$ & $0.285^{* * *}$ & $0.295^{* * *}$ & $0.403^{* * *}$ & $0.408^{* * *}$ & $0.373^{* * *}$ \\
Country FE & YES & YES & YES & YES & YES & YES \\
Year FE & YES & YES & YES & YES & YES & YES \\
R ${ }^{2}$ & 0.449 & 0.460 & 0.469 & 0.382 & 0.391 & 0.408 \\
$\mathrm{~N}$ & 139 & 139 & 139 & 195 & 195 & 195 \\
\hline Stability Test p-value & & & & 0.004 & 0.005 & 0.004 \\
\hline
\end{tabular}

Legenda: ${ }^{* * *}$ denotes significance at $1 \%$; ** significance at $5 \%$; ${ }^{*}$ significance at $10 \%$. 
Table 6. Current Account Balance, dual inflation differential and the Exchange Rate Regime

\begin{tabular}{|c|c|c|c|c|c|c|c|c|}
\hline & \multicolumn{4}{|c|}{ Sample until 2008} & \multicolumn{4}{|c|}{ Whole Sample } \\
\hline & 1 & 2 & 3 & 4 & 1 & 2 & 3 & 4 \\
\hline$\left(\dot{p}_{N}-\dot{p}_{T}\right)-\left(\dot{p}_{N}^{*}-\dot{p}_{T}^{*}\right)_{t-1}$ & $-0.225^{* * *}$ & $-0.207^{* *}$ & $-0.268^{*}$ & -0.061 & $-0.177^{* *}$ & $-0.180^{* *}$ & -0.129 & -0.149 \\
\hline$E R R$ & $2.000^{* * *}$ & & $1.986^{* *}$ & & $1.728^{* *}$ & & $1.727^{* *}$ & \\
\hline FIX & & -1.320 & & -1.951 & & $-2.241^{*}$ & & $-2.366^{*}$ \\
\hline$\left(\dot{p}_{N}-\dot{p}_{T}\right)-\left(\dot{p}_{N}^{*}-\dot{p}_{T}^{*}\right)_{t-1} * E R R$ & & & 0.021 & & & & -0.024 & \\
\hline$\left(\dot{p}_{N}-\dot{p}_{T}\right)-\left(\dot{p}_{N}^{*}-\dot{p}_{T}^{*}\right)_{t-1} * F I X$ & & & & -0.250 & & & & -0.052 \\
\hline Cons & $-9.632^{* * *}$ & $-5.412^{* * *}$ & $-10.530^{* * *}$ & $-5.029^{* * *}$ & $-8.880^{* * *}$ & $-0.688^{* * *}$ & $-9.653^{* * *}$ & $-2.954^{* * *}$ \\
\hline Country FE & YES & YES & YES & YES & YES & YES & YES & YES \\
\hline Year FE & YES & YES & YES & YES & YES & YES & YES & YES \\
\hline $\mathrm{R}^{2}$ & 0.436 & 0.408 & 0.436 & 0.420 & 0.422 & 0.410 & 0.423 & 0.410 \\
\hline $\mathrm{N}$ & 140 & 140 & 140 & 140 & 182 & 182 & 182 & 182 \\
\hline Stability Test $p$-value & & & & & 0.016 & 0.034 & 0.016 & 0.020 \\
\hline
\end{tabular}

Legenda: ${ }^{* * *}$ denotes significance at $1 \% ;{ }^{* *}$ significance at $5 \% ;{ }^{*}$ significance at $10 \%$. 
Figure 1. Foreign (Euro Area) Credit as a share of GDP

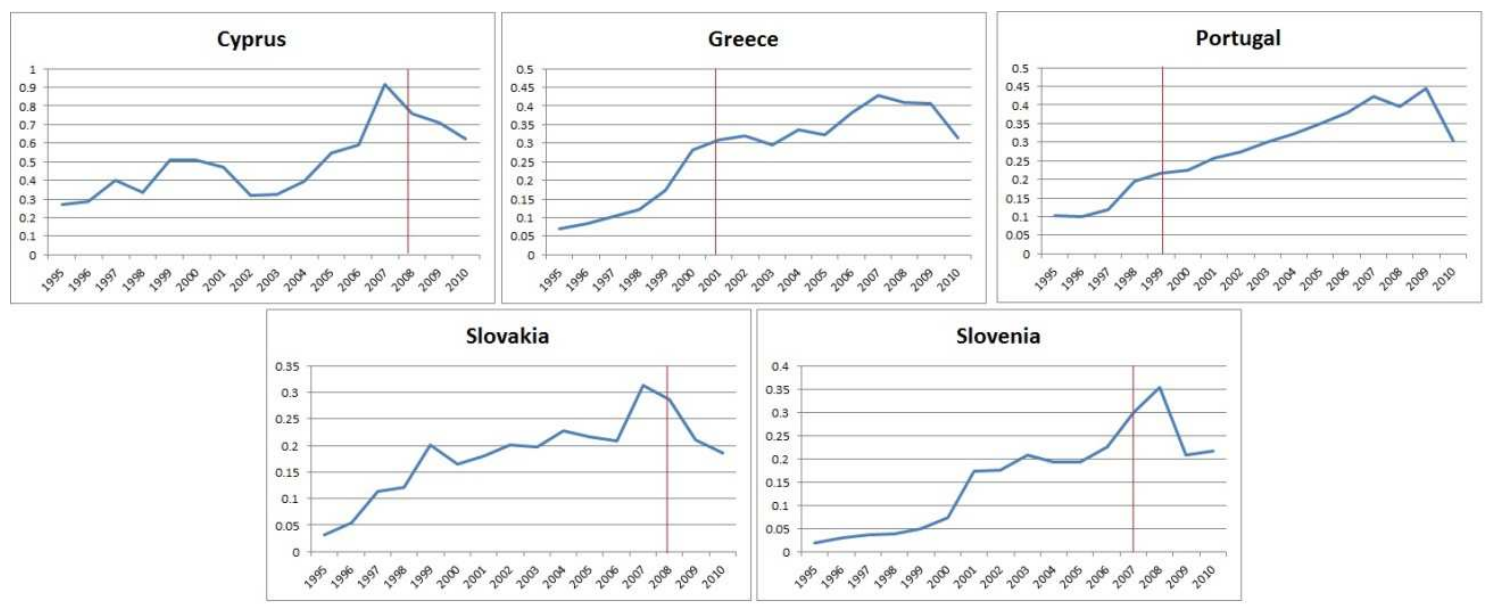

Legenda: The plotted line shows the amount of foreign credit received in each country from other euro area countries, as a ratio of own GDP. The vertical line shows the date of euro adoption. Source: ECB.

\section{Figure 2. Export Market Share}
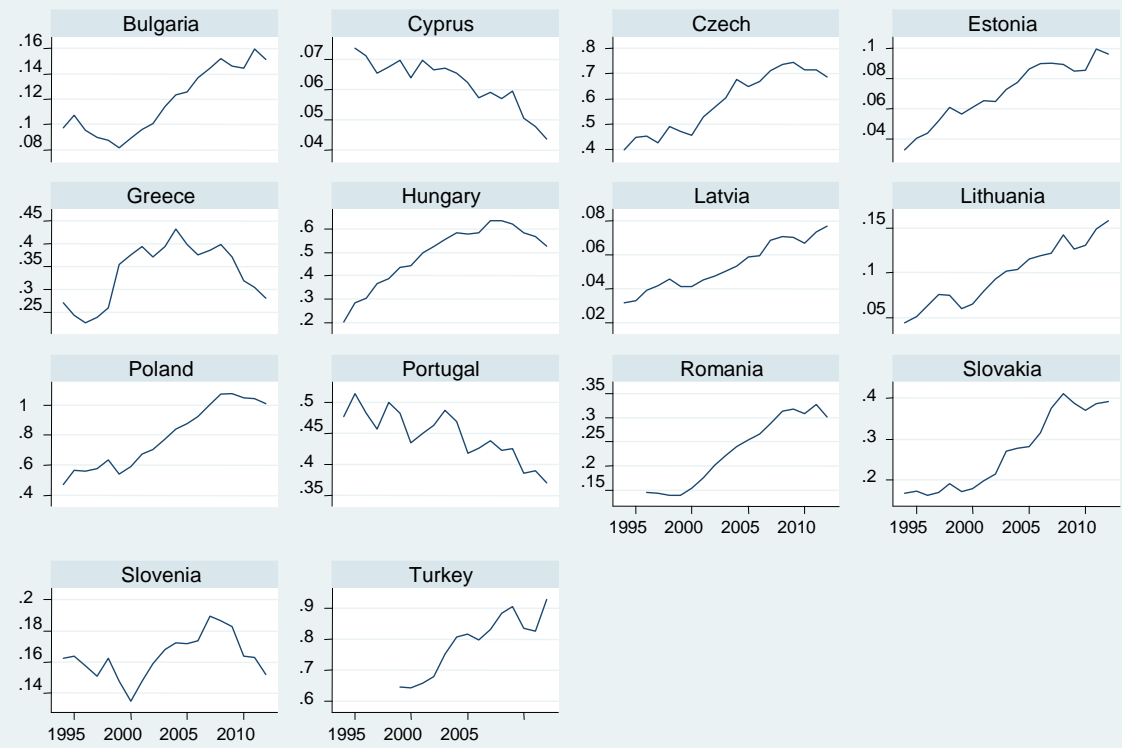

Legenda: See Data Appendix for definition of Export Market Share. 
Figure 3. Current Account Balance
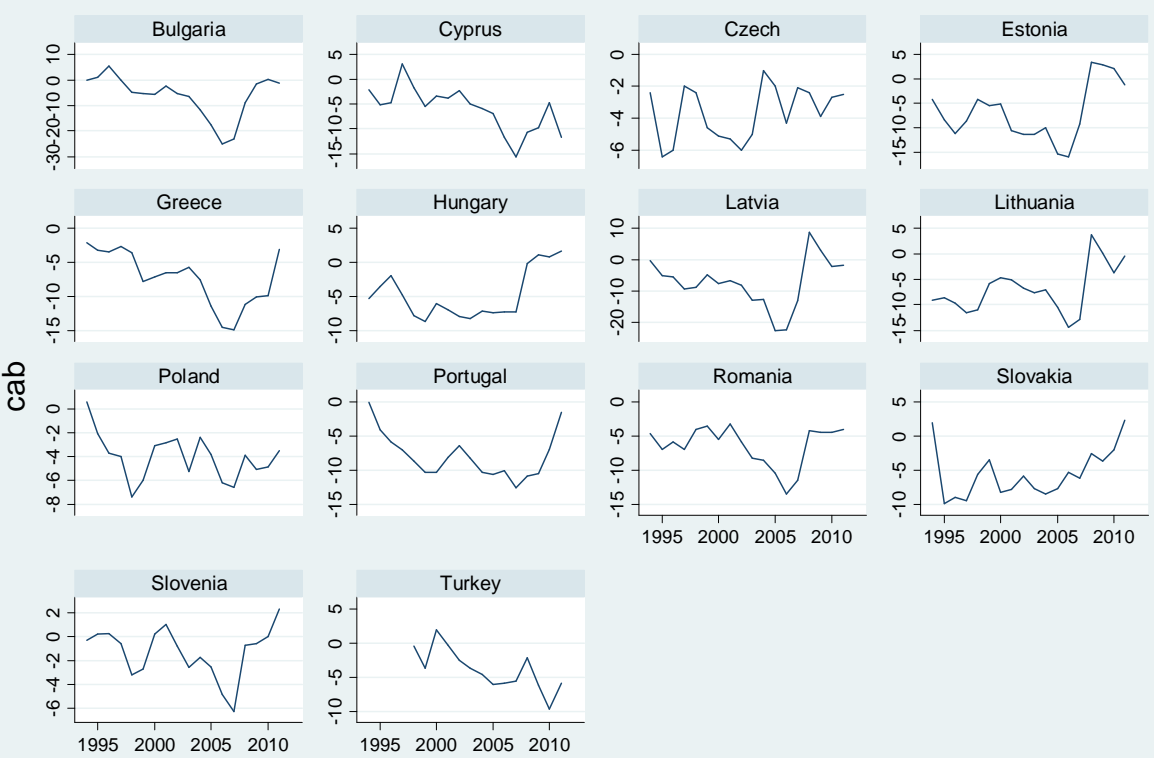

Graphs by country

year

Legenda: Current Account Balance measured as ratio to GDP. Source: Eurostat. 